\title{
6 Theologies and beyond
}

\section{Introduction}

This chapter begins with an examination of the philosophical grounding for R. S. Thomas's 'religious poetry' as found in his 1966 article 'A Frame for Poetry' and in his 1963 'Introduction' to The Penguin Book of Religious Verse. It then examines Thomas's 'mythic' poems by focusing on the 1972 collection H'm. Chapter 7 examines Thomas's 'via negativa' and 'via affirmativa' poems by concentrating on the collections Frequencies (1978) and Destinations (1985), in which these 'types' are most pervasive. This examination of individual collections allows one a view into the most concentrated treatment and development of such themes by Thomas, as well as a deeper grasp of the character of the individual volumes, each of them significant milestones in the oeuvre as a whole. My chief purpose in these final chapters is to highlight and explore what might be called Thomas's 'reconfiguring' of theology, that is, his insistence on the central validity and importance of individual spiritual experience, both as absence and as presence. That insistence radically expands the category 'religious poetry' towards what Thomas calls, in his 'Introduction' to The Penguin Book of Religious Verse (1963), the 'imaginative representation' of an 'experience of ultimate reality' (64). His religious poetry can be seen not merely as 'devotional' but as primarily exploratory of wider dimensions of the notion of deity, and, in particular, the relation of deity to human experiences of suffering, doubt, and despair. Such 'reconfiguring' constitutes one of Thomas's major achievements. Through such reconfiguring he, more than any other recent, poet, reinvigorates the genre of English-language religious poetry, reshaping it to reflect a contemporary spiritual experience, a reshaping which, as M. Wynn Thomas has recently attested, qualifies Thomas as 'an aristocrat of the language and one of the modern world's greatest religious poets' (Jones and Evans, 1999: 13).

The sudden proliferation of R. S. Thomas's 'religious poems' beginning in the 1970s follows closely on his move from Eglwysfach, near the mid-Wales coast, to Aberdaron, on the Llŷn peninsula, in 1967. With the move to Aberdaron in the remote north-west there appears in Thomas's 
poetry a waning of earlier preoccupations with Welsh rural life and the struggle for national identity in favour of an intensification of the personal search for deity. In his autobiography No-one (1986) Thomas writes of himself that 'having reached Aberdaron ... he turned to the question of the soul, the nature and existence of God'. (76). And later in the autobiography:

He wrote political, patriotic poetry in English, and then fell quiet. He portrayed the life of the small farmer as an act of protest against the ignorance and apathy of the rich and the well-off. But through those poems ran a religious vein that became more visible during his last years. After all, there is nothing more important than the relationship between Man and God. (104)

Beginning in earnest with the volume H'm in 1972 it is the vicissitudes of that 'relationship between Man and God' which Thomas's work primarily reflects. ${ }^{1}$ Two significant characteristics emerge with this turning in the 1970s towards a distinctly 'theological' poetry. First, in their drive and method the poems become notably metaphysical, reflecting an intense intellectual drive towards spiritual understanding which is propelled by an equally intense emotional urgency. One finds in these poems an intense compression forged under what seems a barely restrained emotional charge. The poetry becomes 'wrought' in the sense of being 'highly worked', seeking the mind's understanding by force of 'the heart's need'. ${ }^{2}$ One is reminded of Eliot's claim in his lecture 'The Varieties of Metaphysical Poetry' that the major characteristic of such poetry is its 'fusing sense with thought' (1993: 58). While Eliot sees Dante and Donne as the masters of such poetry, he goes on in the lectures to write of the French poet Jules Laforgue as sharing a similar disposition and drive:

He had an innate craving for order: that is, that every feeling should have its intellectual equivalent, its philosophical justification, and that every idea should have its emotional equivalent, its sentimental justification. (1993: 212)

The drive behind, and manifestations within, Thomas's religious poetry beginning with $H^{\prime} m$ are strikingly similar to what Eliot elucidates here: an uncompromising search for natural links between thought and feeling, for an intellectual conception which can adequately answer emotional experience, and, in turn, the contextualisation of those experiences within a viable frame of speculative thought. ${ }^{3}$ One encounters in these poems an often painful yoking of the disparate elements of these 'two 
worlds' as, repeatedly, Thomas presses towards a reckoning between religion and life. ${ }^{4}$

The second significant element which emerges from, and becomes characteristic of, these religious poems is a potent spiritual thirst. While despair is often and rightly discussed as a key element in Thomas's religious poetry, it needs to be added that the quality of that despair is one of intense spiritual yearning or thirst. Eliot helps in this as well. Commenting on Tennyson's In Memoriam in his Essays Ancient and Modern, he writes that

It is not religious because of the quality of its faith, but because of the quality of its doubt. Its faith is a poor thing, but its doubt is a very intense experience. In Memoriam is a poem of despair, but of despair of a religious kind. And to qualify its despair with the adjective 'religious' is to elevate it above most of its derivatives. (1936: 177)

Although clearly Thomas's faith is not 'a poor thing' but, rather, a living thing, that is, stronger or weaker, waxing and waning, but never static, Eliot's main point in these lines never the less seems entirely relevant. Thomas is a religious poet, and even a despairing poet, in precisely this sense, according to the nature of his insatiable thirst for, and drive toward, a spiritual source. Using Eliot's qualification of despair as 'religious' it seems that Thomas's despair, like Tennyson's, is elevated 'above most of its derivatives', that it can be seen not as the collapse of final resignation but, rather, a strenuous suspension, an ongoing tension between searching and waiting, as, for example, in 'Tidal' from the collection Mass for Hard Times (1992):

The waves run up the shore and fall back. I run up the approaches of God and fall back ...

Let despair be known as my ebb-tide; but let prayer have its springs, too, brimming, disarming him; discovering somewhere among his fissures deposits of mercy where trust may take root and grow. (43)

Finally, although I will not be pursuing further any specific parallels between Thomas and Eliot in this chapter, I do want to suggest that 
Thomas's religious poetry is part of the modernist discourse associated with Eliot, a discourse in which the urgency and honesty of the spiritual quest effectively overturns the tradition and register of 'devotional' verse in favour of increasingly more radical approaches to, and wider possibilities concerning, the human search for ultimate meaning. By 'devotional' I mean here primarily that poetry which utilises dogmatic or 'institutionalised' forms, in language, content, or a combination of the two, to make implicit assumptions of a shared faith between writer and reader. In particular I am referring to the use of an immediately recognisable religious register often closely identified with traditional prayers, sermons, and hymns, which indicates an apprehension of deity as benign and present. While I am not arguing against the possible sincerity or merit of such poetry, I am suggesting that Eliot and Thomas are innovative in depicting, in a new register, the reality and urgency of their individual spiritual experiences.

Beginning with H'm (1972), Thomas's 'religious poems' can be viewed as emerging into three branches which I define in these chapters as 'mythic', 'via negativa', and 'via affirmativa'. The poems I have labelled 'mythic' are characterised primarily by an exploration of, and often confrontation with, an anthropomorphised creator-God which is typically distant, impersonal, predominantly fierce, and, often, ferocious. Most often these mythic poems reiterate, in a radically non-traditional way, a creation narrative as a means of examining the nature of a monotheistic God and the ultimate meaning of its relation to humanity. In this way the poems are distinctly 'mythopoeic' or myth-making, theological speculations, allegorical openings into the possibility of underlying truths about the nature of deity. The mythic poems are to be found primarily in the collections H'm (1972) and Laboratories of the Spirit (1975). By contrast, the poems I have signified as 'via negativa' are concerned with the poet's search for a personal deity less anthropomorphised and exterior than ubiquitous and interior. The via negativa poems are most often characterised by a sense of absence as, paradoxically, the earmark of a divine presence, as well as by an often impending spiritual despair, and by asceticism, silence, and waiting as, increasingly, the only available means of spiritual approach. These poems are mainly to be found in the collections Laboratories of the Spirit (1975), Frequencies (1978), and Experimenting with an Amen (1986). Finally, in keeping with the idea of these 'types' as 'branches', one finds, simultaneous to and, as it were, punctuating these mythic and via negativa poems, expressions by Thomas of instances of spiritual presence and affirmation. In these poems one senses Thomas's gradual emergence from an ascetic 
posture of empty waiting and the experience of deity as absence, towards a regained experience of divine presence, towards a resurgence of spiritual hope and the relaxation of a characteristically bitter contention with divinity, towards acceptance, serenity, and even joy. In so far as there is any 'progression' from one 'type' to another it is, loosely and not strictly, a slow evolution by Thomas out of the via negativa stance towards an emphasis on the experience of spiritual presence, towards expressions which can be labelled 'via affirmativa'. This gradual emergence finds its strongest expression in the 1985 collection Destinations, though it occurs intermittently prior to this, and its manifestations continue into Thomas's final work.

\section{Philosophical grounding}

In exploring the philosophical grounding for Thomas's religious poems it is important to emphasise its intellectual breadth. It is according to that breadth that Thomas is able to discard the more 'devotional' models of 'religious verse' while at the same time retaining and re-emphasising, in a new way, what he considers to be the primacy of a 'religious frame' for poetry. His expanded definitions for such terms as 'religious frame' and 'religious truth' enable him to transform and reinvigorate so-called 'religious verse', updating it to accommodate the keen probing, the honest doubt, and, often, the alarming despair characteristic of the search for deity in a postmodern age. I am suggesting that by neither insisting on traditional models of poetic piety nor jettisoning altogether the possibility of religious 'answers' to the searching questions posed by twentiethcentury sensibility concerning the existence of deity and its relation to humanity, Thomas's grounding allows him effectively to transfuse the genre of religious verse by widening its relevance to the whole experience of life.

In his 1966 article for the Times Literary Supplement entitled 'A Frame for Poetry' Thomas argues that 'it is within the scope of poetry to express or convey religious truth, and to do so in a more intense and memorable way than any other form is able to' (90). Although one can infer from the phrase 'within the scope' that, for Thomas, all poetry need not be 'religious', he makes clear his opinion that poetry is somehow uniquely suited to the expression of 'religious truth'. He goes on in the article to suggest a compatibility, what he calls a 'symbiosis', between the two professions of priest and poet, and even suggests the possibility that the conscious abandonment of such a 'religious frame' may propitiate a kind of literary decline: 
So far as we can tell, there are no works of poetry being produced in English today that are of comparable stature with those of Chaucer, Spenser, Shakespeare or Milton. Whether these writers themselves were avowedly Christian or not, they wrote within a Christian framework. Is there a relation between the decline of Christianity .... and the decline in works of high poetry? Many like to associate poetic decline or inferiority with a consciously adopted Christianity, Wordsworth being the locus classicus. But why blame Christianity for our failure to produce high poetry, if Christianity is no longer a major force in our culture? (92)

Thomas raises three important questions by his suggestion in these lines that religion forms the proper frame or context within which poetry can do its best work. First, what, for Thomas, constitutes the 'religious framework' of poetry? Second, what is the nature of the 'religious truth' which he feels poetry is so aptly suited to express? And third, what is the nature of the relation Thomas seems to envisage between religion and poetry? Because Thomas was a priest in the Anglican Church in Wales for forty-one years (1937-78) and a poet engaged deeply with philosophical questions concerning the existence of deity and the nature of its relation to humanity, his answers to these questions become central to an understanding of his life and work.

It is in his 'Introduction' to The Penguin Book of Religious Verse (1963) that one begins to find answers to these questions and, as such, the 'Introduction' becomes indispensable to an understanding of the philosophy which underlies Thomas's religious poems. In the 'Introduction' Thomas defines religious poetry as the 'imaginative representation' of 'an experience of ultimate reality' (64). He warns of this definition as 'sticking somewhat loosely to orthodoxy', and one can immediately see that 'imaginative representation' and 'ultimate reality' allow for tremendous leeway, both on the side of poetry and on the side of 'religious truth'. In particular, use of the term 'ultimate reality' broadens the category not only beyond the doctrinal confines of the Christian Church but beyond institutionalised religion as a whole. The phrase is clearly subjective in its application, allowing for a wide-ranging multiplicity in the understanding and experience of divinity. ${ }^{5}$ Thomas's subject divisions in the anthology into 'God', 'Self', 'Nothing', 'It', 'All', are examples of this wide view of what constitutes 'ultimate reality'. In particular the category 'Nothing' significantly widens the traditional parameters of 'religious poetry' by making room for expressions of spiritual absence and despair. Thomas writes that: 
Neither the Middle Ages' obsession with death, nor the ability of contemporary poets such as John Crowe Ransom to describe despair so movingly, are necessarily indicative of their satanic allegiance. Poems such as the 'terrible' sonnets of Gerard Manley Hopkins are but a human repetition of the cry from the Cross: 'Eloi, Eloi, lama sabachtani?' The ability to be in hell is a spiritual prerogative, and proclaims the true nature of such a being. (66)

Thus, while he readily admits in the 'Introduction' to attempting 'to broaden the meaning of the term "religious" to accommodate twentieth-century sensibility', and while he owns that such an attempt may 'arouse the indignation of the religious, more especially the Christian, reader', Thomas defends these efforts at expansion with the assertion that 'it is not necessarily the poems couched in conventionally religious language that convey the truest religious experience' (65). His claim is that 'wherever and whenever man broods upon himself and his destiny, he does it as a spiritual and self-conscious being' (66). According to this statement most, if not all, of Thomas's poems, overtly religious or not, would fall within the parameters of a new 'religious poetry', an indication, again, of the wide breadth of his view. ${ }^{6}$ Such observations by Thomas in the 'Introduction' are not merely prefatory to his choices for the anthology, but are important indicators of the broad mind-set out of which his own religious poems can be better understood. To borrow an expression from Douglas Dunn's appraisal of Hugh MacDiarmid, Thomas's religious poetry is 'not an art of simple rediscovery so much as one of transfiguration in the crucible of modern sensibility' (1992: xix).

According to these definitions one can begin to see more clearly Thomas's answers to the three questions raised above. In answer to the first question it becomes apparent in the 'Introduction' that, for Thomas, a 'religious frame' is composed not of a body of dogma but, rather, of belief in an 'ultimate reality' which is primarily experiential and therefore subjective. Likewise, concerning the nature of 'religious truth' posed in the second question, it is, Thomas suggests, the individual experience of that 'ultimate reality', again, a 'religious truth' clearly unconfined by traditional religious dogma. In answering the third question concerning the nature of the relation between religion and poetry Thomas's answer is implicit in the foregoing responses: the relation between religion and poetry is, for Thomas, clearly organic. The individual's subjective experience of ultimate reality itself becomes the natural stuff of poetry. Indeed, according to his own definitions, to cast off the 'religious frame' 
for poetry is, for Thomas, to abandon poetry itself since what Thomas calls 'the frame' is at once religious frame, religious truth, and poetic substance. In the 'Introduction' he further suggests, with Coleridge, that the imaginative expression of the experience of ultimate reality in poetry not only imitates but very nearly partakes of the action of deity itself. $\mathrm{He}$ writes:

The nearest we approach to God he [Coleridge] seems to say, is as creative beings. The poet by echoing the primary imagination, recreates. Through his work he forces those who read him to do the same, thus bringing them nearer the primary imagination themselves, and so, in a way, nearer the actual being of God as displayed in action. (64)

According to this, the act of writing, the imaginative expression of the experience of ultimate reality, as well as the act of reading, the reflexive imagining of that experience, become a transformation, a meta morphosis of writer and reader into the process, and therefore the very being, of deity. Together with his definition of religious poetry as the 'imaginative representation' of 'ultimate reality', this suggestion of the poet as 'echoing the primary imagination', as uniquely recreating, points to a philosophical grounding in Thomas which is significantly wider than is often supposed. And it is this intellectual 'breadth' that is one of the most important characteristics and contributions of Thomas's religious poems: the expansive and inclusive nature of his intellectual position regarding the personal experience of ultimate reality as the essential raw material of poetry.

\section{Mythic: the shock of $H^{\prime} m$}

The shock of the collection H'm (1972) begins with its opening poem, 'Once', which features all of Thomas's mythic elements. First, the poem is distinctly mythopoeic or myth-making, reworking a creation narrative which, while not perhaps 'true' in its literal sense, is none the less meant to probe 'truths' concerning the human condition which transcend the confines of physical time and space. Second, the poem's mode is clearly prophetic-apocalyptic, that is, authoritative in tone (prophetic) and visionary in aspect (apocalyptic). Third, the poem features an anthropomorphised creator-God, omnipotent and 'other', the object of fear. Finally, underlying the poem's text one discovers an implicit imaging and questioning of that creator-God, and even of creation itself, concerning human meaning and purpose. When viewed in conjunction with the 
second point above, this final characteristic bears an irony worth noting. While 'Once' is singularly authoritative in tone, it is also singularly speculative in its underlying drive. While the poem's rhetoric is deliberately fashioned to assert 'truth' in clipped, bold declaratives, beneath this mask of infallibility the poem is an expression primarily of possibility. Thus 'Once' is effectively split in its 'personality'. Driven at its source by a questioning angst, its manifestation, its overriding poetic voice and gesture, remain cool and self-assured, strangely unquestionable in the authenticity of its authority. It is important to recognise this discrepancy since it indicates these mythic poems to be, fundamentally, theological probings and even deconstructions by Thomas of monotheism and its relationship to the actual, physical, and human world, what J. P. Ward, in his book The Poetry of R. S. Thomas, refers to as 'the mythic figuring and refiguring of God' (1987:84). ${ }^{7}$ With $H^{\prime} m$ Thomas presses forward in an intensely focused way towards the discovery of a religious understanding which can match experience. Indeed, D. Z. Phillips, in his book R. S. Thomas: Poet of the Hidden God, views $H^{\prime} m$ as finally relinquishing the poet's search for a 'theodicy' which can answer the charge of human suffering and as embracing, rather, a deity whose very identity is somehow intimately bound up in that suffering. In highlighting this embrace, Phillips not only underscores the radical nature of Thomas's religious stance but also suggests that Thomas's answer to the philosophical 'problem of evil' is a view of deity characterised not by the divided imperatives of omnipotence or love, but by an omnipotence which is love, which is 'self-emptying' and which therefore encompasses both the good and evil, a sordid combination which the poet finds endemic to human existence. Such a view of divinity, according to Phillips, allows Thomas a faith response in keeping with his own experience:

The poet turns his back on the kind of religious impulses which seek to explain away the torment and suffering in the world. The poet insists that such facts must be embraced rather than ignored ... The poet shows us a religious faith which actually depends on embracing the mixed character of human life in a way which does not deny its character. (1986: 77)

My main point here is that the mythic poems are not merely an intellectual exercise for Thomas but are attempts to render religion in terms of actual human experience without denying or over-simplifying, in language or content, either one. This section focuses closely on the mythic poems as, specifically, examples by Thomas of theological expansions towards what might be called a 'spiritual realism', a reworking of more 
dogmatic structures in favour of a poetic grappling with spiritual struggle, and even paradox, which is nearer, both in its language and its substance, to individual spiritual experience than to stricter theoretical constructions of the objective nature of God.

'Once', the opening poem of H'm, begins with God's creation of Adam, the first man, significantly a poet, who narrates his own beginnings:

\author{
God looked at space and I appeared, \\ Rubbing my eyes at what I saw. \\ The earth smoked, no birds sang; \\ There were no footprints on the beaches \\ Of the hot sea, no creatures in it. \\ God spoke. I hid myself in the side \\ of the mountain. (1)
}

The creation of man in these lines occurs not as the biblical formation by God from clay, but as a conjuring from space, a nearly comic sleight of hand. There are, however, two other aspects to focus on in these lines. The first is the man's reaction to the sight of the created world around him, the second his reaction to the sound of God's voice. The man rubs his eyes at the sight of the created world, presumably in some wonder, and yet we can infer from the description of the world in lines 3-5 that it is a wonder at least partially tinged with fear:

The earth smoked, no birds sang;

There were no footprints on the beaches

Of the hot sea, no creatures in it.

The creation here may be pristine, but it is also primeval and desolate, as yet untamed by occupation or age, and hence, if only by implication, dangerous. We also find in these opening lines that, despite the apparently 'unfallen' state of the man, the voice of God precipitates in him fear, flight, and hiding: 'God spoke', we are told, and 'I hid myself in the side / of the mountain'. While Thomas leaves the reader to guess precisely what that divine utterance might have been, what is most important here is that the sound of that voice, the first sound of that voice, the first communication between creator and created, elicits not trust or comfort in the man but fear and an instinctual flight towards self-preservation from what is perceived to be a singularly threatening deity. This sense of the created world as lonely and dangerous, and of deity as mighty and fearsome, is amplified in the poem's second and final stanza. Thomas writes: 
In the brown bark

Of the trees I saw the many faces

Of life, forms hungry for birth, Mouthing at me. I held my way

To the light, inspecting my shadow

Boldly.

The sense in these lines is of life as a journey, an important motif for Thomas, but, more specifically, an uncertain journey in which the poet is forced to hold his 'way / To the light', a journey plagued by shadow and pain, and the mouthing 'faces of life', 'hungry for birth'. These ideas of a distant God, of life as a journey through the 'dark' of longing, of the necessity of a courageous probing of one's shadow-self, of the stamina required for holding one's way to 'the light', are characteristics central to Thomas's understanding of human existence, and it is in these mythopoeic renderings that one can see them most plainly and powerfully united.

In the final lines of 'Once' the poet introduces Eve as 'rising towards me out of the depths / Of myself'. This evocation of the creation of woman is striking and important. By substituting the biblical formation of Eve from the sleeping Adam's rib with this awareness by the man of her organic growth out of his own vital substance, Thomas intensifies an intimacy between the two which compensates for their apparent alienation from the creator, as well as their apparent loneliness within the natural world they are to inhabit. More than companion and counterpart, the two are, Thomas suggests, one and the same. ${ }^{8}$ In the poem's final lines Thomas further consolidates that intimacy and its compensatory force in the hostile world that awaits them:

I took your hand,

Remembering you, and together,

Confederates of the natural day,

We went forth to meet the Machine.

In these final lines one finds not only a powerful affirmation of human intimacy, but the necessity of that intimacy within the natural context of war. The two key words in these final lines are 'Confederates' and 'Machine', indicating as they do that the man and woman enjoy not only a mystical union of sorts but a military objective as allies against 'the Machine'. While Thomas refrains from defining 'the Machine' here, his use of the word as a proper noun indicates it to be a force of evil which stands pitted against the couple. And while this image is capable of being contextualised within a Christian framework, these final lines seem to 
hint more than a little towards a kind of Zoroastrianism in which the forces of light and dark are seen to march forth into battle for possession of the world. Thomas seems to be suggesting in 'Once' not only the inexplicable reality of evil but the nature of existence as a warring struggle against that reality, in which divinity has relinquished its omnipotent hold and in which ultimate outcomes have yet to be determined.

What we discover, then, in 'Once' is a poem which pursues insight into both the nature of deity and into the nature of human existence by re-posing, re-inventing, and re-interpreting traditional 'actions' of a monotheistic creator-God. These philosophical or imaginative reworkings form the core of virtually all of Thomas's mythic poems. What is striking in this regard is that while Thomas's probings in the mythic poems remains constant, his conclusions often range. While one may infer a certain philosophical 'picture' or 'position' from a poem such as 'Once', that conclusion is very likely to stand more or less at variance with depictions in alternative mythic poems. Largely because of such speculative variance on Thomas's part, the mythic poems, as a whole, are both complex and dynamic, as opposed to simple and static replications of a given formula.

Of the thirty-seven poems which make up the collection H'm, fully eleven can be labelled 'mythic' according to the characteristics I have already discussed above. Having examined 'Once', I will now turn to five of these poems in order to underscore, despite the similarity of their means, their alternating emphases and conclusions and, in doing so, to encourage a view of Thomas's mythic poems not as static or repetitive but as creating, by their cumulative effect, a kind of philosophical montage of intensified spiritual pursuit. Indeed, a sequential comparison of these five poems indicates a pattern with regard to Thomas's depiction of deity which, beginning with divine indifference, goes on to alternate between divine violence and divine compassion, finally ending in a curious synthesis of all of these characteristics. This alternating pattern encompasses, in total, the following six poems: 'Echoes' (4), 'Making' (17), 'Island' (20), 'Repeat' (26), 'Soliloquy' (30), 'The Coming' (35). I will examine four of these poems in addition to 'Once', as an introduction, and 'Other', as an example of the synthesis Thomas finally achieves between these two alternating poles of divine violence and compassion.

Although in 'Once' Thomas images deity as secondary to the ruminations of the man, in 'Echoes', just a few pages later that deity becomes both central and active. The first nine lines of the poem revolve around three central elements. First, the separation between divinity and its creation; second, the imperious and consuming anger of that divinity; 
and third, the pain experienced by the creation as the result of these. Thomas begins the poem:

\author{
What is this? said God. The obstinacy \\ Of its refusal to answer \\ Enraged him. He struck it \\ Those great blows it resounds \\ With still. It glowered at \\ Him, but remained dumb, \\ Turning on its slow axis \\ Of pain, reflecting the year \\ In its seasons. (4)
}

These lines indicate a creator-God alienated from its own creation and 'enraged' by such unaccountable separation to the point of violence. However, concerning the sources of such alienation and violence there is a certain ambiguity. For example, God's question 'What is this?' indicates a concealed referent. Similarly, we find a strange 'obstinacy' in the earth, an unexplained 'refusal to answer'. Even after the 'great blows' dealt it by God the creation remains unaccountably 'dumb'. What is clear in these lines, and what appears most important to Thomas in the poem thus far, is that this suffering of the creation, whatever its ultimate source, is a defining characteristic, the 'slow axis / Of pain' on which it is doomed to turn. In the poem's second half God's 'answer' to the 'dumb' earth, a dumbness which underscores God's essential loneliness and the need, in so far as one can posit divine need at all, for intimacy or relatedness with a seemingly independent creation, is to create animals and, ultimately, human beings:

\footnotetext{
God looked at it

Again, reminded of

An intention. They shall answer

For you, he said. And at once

There were trees with birds

Singing, and through the trees

Animals wandered, drinking

Their own scent, conceding

An absence. Where are you?

$\mathrm{He}$ called, and riding the echo

The shapes came, slender

As trees, but with white hands,

Curious to build.
} 
It seems at first in these lines that God's overriding need for communication, for dialogue with the creation, may be indicative of a divine compassion defeating the earlier impulse to punish. But despite the ability of the new creatures to communicate, to 'answer', they do so by 'conceding an absence'. In so far as these creatures possess a 'knowledge' of their origin, it is as absence only. The gap, the uncomfortable silence between creator and created remains. God is forced to utter the cry 'Where are you?', and humanity hears that call not directly, but only faintly, as 'echoes' they must 'ride'. The implication of distance is explicit. In the final lines of the poem the communication which finally does occur across that distance between the humans and God comes in the form of blood, of sacrifice:

\section{On the altars}

They made him the red blood told what he wished to hear.

What is shocking in these final lines is the blatant absence of any divine compassion. One finds here that Thomas's God has shifted from pining for intimacy to demanding satisfaction, homage, sacrifice. What one finds in 'Echoes' is not a silent or indifferent god but a divinity whose wounding, rather than giving way to a more deeply loving regard, requires blood.

Having highlighted the divine indifference of 'Once' and the divine violence of 'Echoes', one finds in the poem 'Making' the emergence, finally, of divine compassion. Before examining this development however, it is important to stress a basic continuity established by Thomas in these three poems and, indeed, in the mythic poems as a whole. In addition to their opening with similar images of an anthropomorphised creator-God at work, 'Once', 'Echoes', and 'Making' are all characterised by an ethos of overwhelming loneliness and alienation.

In 'Once' not only does man hide himself 'in the side / of the mountain' upon hearing God speak, he is similarly alienated from the rest of nature, which, in its own turn, is removed from the divine. Thomas writes that

In the brown bark

Of the trees I saw the many faces

Of life, forms hungry for birth,

Mouthing at me. (1)

The loneliness and alienation that are common and central to these poems are reflected in these anonymous 'faces', 'forms' without voice 
which are desperate for a 'birth' denied them. The faces are isolated and haunting, just as the narrator of the poem is himself isolated and haunted by them.

In 'Echoes' one finds a similar fault-line or separation by which God becomes enraged at the creation for its dumbness, its 'refusal to answer', and punishes it accordingly. This divine propensity for violence is further echoed in God's sinister spreading of bacteria in 'Making' (4). Nature, in 'Echoes', remains unconnected from its source in the divine, 'conceding / An absence'. And finally, God in the poem is forced to call out to the humans, 'Where are you?', who hear only the echoes of that cry over the distances between.

In 'Making' nature is depicted, again, as 'faces' which 'stared in / From the wild', an image which clearly creates an inside/outside dichotomy and the sense of a barrier, as of glass, not to be transgressed. The existence of nature is not indicative of its deeper presence in relation to divinity, forcing God to admit:

Yet still an absence

Disturbed me. (17)

'Once', 'Echoes', and 'Making' are poems in which God, nature, and humanity exist in fragmentation, alienation, and essential loneliness, rather than in a more organic connection. Such alienation forms the overriding ethos, the most basic premise, the common ground and frame out of which the poems emerge. It is precisely this frame which ties the mythic poems into a single developing body. While, as we shall now see, Thomas's depiction of deity in 'Making' stands in stark contrast to his depictions in 'Once' and 'Echoes', that contrast emerges from within this common ground. Viewed in this way the individual mythic poems can be seen not as contradictions, but subtle modulations or counterpoints, not primarily as individual works, although they are clearly capable of standing alone, but as a succession of movements in a musical suite.

The final lines of 'Making', while emerging from this common ground, none the less indicate a substantial development in Thomas's depiction of the nature of divinity. God, as the narrator, relates:

I slept and dreamed

Of a likeness, fashioning it, When I woke, to a slow

Music; in love with it

For itself, giving it freedom

To love me; risking the disappointment. (17) 
Here, finally, is the God of love so painfully absent from 'Once' and 'Echoes'. These lines reveal not only the selflessness of the love-force underlying the act of creation but the empowerment of that creation via free will, and the acceptance, by God, of a necessary vulnerability as the result of such empowerment. What we have in 'Making' is thus the complement to 'Echoes' rather than the contradiction. Thomas is not, in these poems, restricting divinity to wrath or love but, rather, driving forward speculations, drawing out strands in a philosophical reckoning with the whole idea of monotheistic divinity. Far from any narrow assertion of a single truth, Thomas is widening the approach in these mythic poems to an understanding not so much of what divinity is, but of what divinity could be, holding up, at the same time, the possibility, and perhaps even the necessity, of paradox as the defining characteristic of such an answer.

Finally, as yet another aspect of this 'comprehensive effect' it should be noted that although in 'Once' Thomas narrates in the first-person omniscient as the man, and while in 'Echoes' he narrates in the thirdperson omniscient as the narrator, in 'Making' he, for the first time, assumes the first-person omniscient as God. These shifting perspectives in the mythic poems are an effective means of directing reader focus. In 'Once' the reader is primarily drawn down, into what Thomas views as the predicament of human existence; in 'Echoes' the reader is forced out, to the wider perspectives of relationship between God, creation, and humanity, and in 'Making' the reader is taken in, to speculation on the more precise and fundamental nature of deity. Again, these shifting perspectives, when seen together, serve to broaden rather than to restrict the theological context of Thomas's probing.

If 'Making' introduces into the mythic poems the possibility of love as the predominant characteristic of a creator-God, 'The Island', just a few pages later, reverts in its emphasis to a deity of wrath and thereby highlights the alternating pattern of these mythic poems in $H^{\prime} m$ between depictions of divine violence and compassion:

And God said, I will build a church here

And cause this people to worship me,

And afflict them with poverty and sickness

In return for centuries of hard work

And patience. (20)

Whereas in 'Making' human free will is the chief manifestation of divine love, in these lines the retraction of that free will seems to be the effect of divine displeasure: 'I will build a church here / And cause this people 
to worship me'. The disappointment risked by God in 'Making' has been not only realised here but, as in 'Echoes', transposed to anger, the clear inference being that humanity, according to Thomas, has not, of its own free will, chosen the practice of worship. These opening lines indicate not only a divine anger, jealousy, and outrage but the determination by deity to compel such worship through force of superior strength, to grind humanity into dependence by affliction with poverty, sickness, and pain, despite 'centuries of hard work / And patience'. In the remaining four lines of the first stanza the omniscient narrator proceeds to describe this failure of humanity in terms of the physical structure which God, in the poem's opening line, vows to construct:

And its walls shall be hard as

Their hearts, and its windows let in the light

Grudgingly, as their minds do, and the priest's words be drowned

By the wind's caterwauling.

It is, for Thomas here, a human lack of receptivity to the divine, a lack of acceptance of and dependence on the divine to which God reacts: the hard heart, the grudging mind, the deaf ear. And yet what seems so disturbing in the poem as a whole is, first, that the punishment which God metes out for such 'failings' seems disproportionately severe and, second, that divinity becomes virtually consumed by human emotion, by offended love, essentially by grief, and subsequently seeks to redress that grief through a brutal exacting of revenge:

All this I will do,

Said God, and watch the bitterness in their eyes

Grow, and their lips suppurate with

Their prayers. And their women shall bring forth

On my altars, and I will choose the best

Of them to be thrown back into the sea.

In these lines God's wrath appears frighteningly unbounded. Not only that, there seems, perversely, to be a divine enjoyment of the long suffering of humanity. Thomas ends the poem with the declaration:

And that was only on one island.

While the narrator seems to wink from behind this final line in a kind of tongue-in-cheek acknowledgement of the poem's extremity and severity, it is, none the less, a grim humour which does little to subvert the 
poem's dark concern. 'The Island' raises and sustains the question whether Thomas in these mythic poems embraces a decidedly malevolent creator, a Puritan God of wrath, bent on the punishment, through suffering, of human sin.

While the answer to this question may appears to be 'yes', it helps to view 'The Island' not as a strict philosophical 'answer' by the poet but as driven by Thomas's longing to understand human suffering. The poem's ultimate preoccupation is with the source of, and reason for, poverty, sickness, pain, and loss. In dealing with this 'problem of pain' Thomas is faced again with the paradox of a New Testament God of compassion and forgiveness and the relation of that God to human suffering. Thomas, rather than embracing a malevolent God, is exploring in 'The Island', as a possible answer, the model of an Old Testament God of the sort found in the Pentateuch and the Psalms, whose passion is characterised not only by love and forgiveness, but by demands, conditions, anger, jealousy, and wrath. The God of 'The Island' is most productively viewed as a single exploration of a single aspect of monotheism, and is significantly restricted by removal from its proper context in the mythic poems as a whole.

As if to drive home this necessity of viewing the individual mythic poems as creating an alternating pattern within the wider context they form together, Thomas provides us in 'The Coming' with a configuration which emerges from this Old Testament grounding to anticipate the Christian incarnation. Central to 'The Coming' is not God's wrath but the helpless state of humanity and the son's pity, upon witnessing that state, as the key to the Christian incarnation, crucifixion, and redemption. In marked contrast to 'Echoes' and 'The Island', it is not the divine infliction but the divine alleviation of human suffering which is central to 'The Coming'. Thomas writes in the first stanza:

And God held in his hand

A small globe. Look, he said.

The son looked. Far off, As through water, he saw

A scorched land of fierce

Colour. The light burned

There; crusted buildings

Cast their shadows; a bright

Serpent, a river

Uncoiled itself, radiant

With slime. (35) 
As in so many of Thomas's mythic poems, one becomes aware at once of the distance, the metaphorical gap, between creator and creation. Though deity in these lines holds the earth 'in his hand', the son sees it 'Far off, / As through water'. Even the title 'The Coming' indicates the separation inherent to the relationship. Most important here, however, is the narrator's description of the earth as barren waste, a stage of divine neglect and human suffering. It is, Thomas tells us, a land scorched, burned by light, littered with crusted buildings, radiant not with beauty but with slime. Indeed, Thomas's description of 'a bright / Serpent, a river' can be seen, by its effective inversion, as an allusion to earth as the habitation of evil. This is, it seems, the earth after 'He struck it / Those great blows it resounds / With still' in 'Echoes', or after the affliction of 'poverty and sickness' dealt it in 'The Island'. In the poem's second stanza Thomas focuses this broad, aerial view down to a more particular place and people:

On a bare

Hill a bare tree saddened

The sky. Many people

Held out their thin arms

To it, as though waiting

For a vanished April

To return to its crossed

Boughs.

Though the poem's action is chronologically prior to the Christian incarnation, clearly the yearning in these lines is a collective, platonic 'remembering', a prefiguration or prolepsis of the Christian crucifixion or redemption to come, the 'bare / Hill' being Calvary, the 'bare tree' and 'crossed / Boughs' the as yet untenanted cross. In the same way, the 'vanished April' for which the humans pine can be seen both as an assertion of some remembered Eden, a state of union prior to the human alienation from divinity, and as the Easter resurrection. ${ }^{9}$ The whole ethos of the lines is one of sorrow and yearning. Remembering God's decree in 'The Island', 'I will ... cause this people to worship me', we find in 'The Coming' a people brought to their knees by suffering, worshipping out of need. One might argue that it is precisely that need which creates the receptivity towards, and acknowledgement of dependence upon, deity which Thomas laments as lost in 'The Island' and which, ultimately, elicits the action of divine love in the poem's closing lines: 
The son watched

Them. Let me go there, he said.

The act of sacrifice embraced by the son in order to restore a 'vanished April' to suffering humanity is, for Thomas in 'The Coming', the fulfilment of Old Testament narrative as it is re-invented in the mythic poems 'Echoes', 'Making', and 'The Island'. What we can see developing in the mythic poems of H'm is a meditation on Judaeo-Christian monotheism and its gradual movement from Old Testament to New Testament paradigms. The context of 'The Coming' is, necessarily, the mythic poems which precede it, on which it hinges, and of which it is, at least partially, the fulfilment. Thomas, at least in part, intends these mythic poems as a theological reconsideration, and even deconstruction, of deity.

'Other', the penultimate poem of H'm, provides a synthesis of the disparate images of the divine which have preceded it in the poems 'Echoes', 'Making', 'The Island', and 'The Coming'. I am suggesting not that 'Other' is some kind of deliberate unification or knitting together by Thomas of these paradoxical images of deity, but merely that it reflects divinity as characterised both by jealousy, resentment, and wrath, as well as by sensitivity, grief, and compassion. For example, in 'Other' Thomas writes of God's relationship to creation by stating:

\author{
He loved and \\ Hated it with a parent's \\ Conceit, admiring his own \\ Work, resenting its \\ Independence.
}

This simultaneous pride and resentment towards creation is a combination of ideas found to be strictly isolated in the mythic poems so far, embodying both the ferocity of 'Echoes' and 'The Island' as well as the deeper empathy of 'Making' and 'The Coming'. As in 'Echoes' and 'The Island', God is effectively ignored and excluded by the creation in 'Other' and with a similar result:

\title{
There were trysts
}

In the greenwood at which

He was not welcome. Youths and girls,

Fondling the pages of

A strange book, awakened

His envy. ... 
He began planning

The destruction of the long peace

Of the place.

These 'trysts / In the greenwood' between 'Youths and girls / Fondling the pages of / A strange book', while reminiscent of Hawthorne's 'Young Goodman Brown' or Arthur Miller's The Crucible, in which young Puritans dabble in evil, are, according to Thomas in 'Other', strayings which arouse a divine envy and lead, ultimately, to God's determination, once again, to inflict suffering. However, in contrast to the mythic poems examined thus far, once that destruction is under way, God, in compassion, relents:

He began planning

The destruction of the long peace

Of the place. The machine appeared

In the distance, singing to itself

Of money. Its song was the web

They were caught in, men and women

Together. The villages were as flies

To be sucked empty.

God secreted

A tear. Enough, enough,

He commanded.

It is not clear in these lines whether the appearance of 'the machine' is the direct result of God's planned destruction or whether that appearance occurs independently of a divine plan. The question arises in 'Other' whether the machine originates as a kind of divine punishment or whether it is an evil somehow exterior to and independent of that divinity. Whatever the answer to this, God's command that its destruction should cease comes in the poem not authoritatively but as a cry of empathy, a pleading in tears, not as the completion of justice but as an intimate compassion for humanity, much the same as we have seen in 'Making' and 'The Coming'.

In the grim final line of 'Other' the narrator declares that

the machine

Looked at him and went on singing.

In this final mythic poem from $H^{\prime} m$ deity is ultimately defeated. More important, however, is Thomas's suggestion that human suffering continues simultaneous to and independent of divine love and compassion, 
that while divinity suffers with humanity, it is none the less somehow incapable of defeating that suffering and, finally, that while prone to envy, wrath, and punishment, divinity is, at least in 'Other', predominantly loving, suffering its alienation from humanity in the same way that humanity suffers its alienation from the divine. I am not suggesting that 'Other' brings the mythic poems of H'm to a neat philosophical close. On the contrary, it indicates the ongoing complexity, the subtle shifting and probing of Thomas's mythic poems, their sustaining of a paradoxical tension and the need to view them not so much as independent entities but primarily as a body of poems in relationship, whose wider speculations and implications arise not from isolation but from 'abrasion', from the friction of a wider contextualisation.

\section{Notes}

1 The volume proves to be a turning point not only in terms of subject matter. With H'm Thomas moves away from his early use of traditional rhyme and metre towards the free-verse and syntactical experimentation of his later work, as well as from his long-term publisher, Rupert Hart-Davis, to the London-based Macmillan.

2 The phrase 'the heart's need' is Thomas's own, occurring for the first time in 'The Lonely Farmer' (An Acre of Land, 1952) and again in 'Taliesin 1952' (Song at the Year's Turning, 155).

3 John Ackerman, in his valuable study Welsh Dylan: Dylan Thomas's Life, Writing and His Wales (1998), echoes Eliot's definition, perceptively highlighting a similar quality in the work of Dylan Thomas.

4 Eliot makes quite clear his estimation of the power of such poetry when he writes that 'Humanity reaches its higher civilisation levels not chiefly by improvement of thought or by increase and variety of sensation, but by the extent of co-operation between acute sensation and acute thought' (220-1).

5 It is likely that Thomas inherited the phrase from Bishop John Robinson, who uses it in his influential book Honest to God (1963): 'God is, by definition, ultimate reality. And one cannot argue whether ultimate reality exists. One can only ask what ultimate reality is like' (29).

6 Dylan Thomas's declaration concerning his own work that 'These poems, with all their crudities, doubts, and confusions, are written for the love of Man and in praise of God, and I'd be a damn' fool if they weren't', seems underpinned by an understanding of 'religious poetry' arguably similar to that of R. S. Thomas's here (1993. 'Author's Note'). Again, much, if not all, of Dylan Thomas's work might fall within these broadly defined margins, and indeed, R. S. Thomas includes him in the Penguin collection.

7 Robert Langbaum, in his The Poetry of Experience, suggests that the dramatic monologue offered Victorians the 'objectification' or distance between poet and narrator they sought following what they often viewed to be a Romantic indulgence in the subjective first-person stance. Thomas's mythic poems can be seen 
to function in much the same way, as creating a distance or even persona from which to explore 'objectively' philosophically complex and often paradoxical points of view, while at the same time allowing the poet to 'dramatize an emotional apprehension in advance of or in conflict with his intellectual convictions' (1957: 104). Taking Langbaum further, Carol Christ suggests that such objectifiying devices or masks function for the poet not only as 'defensive armor' but as a means of access to an 'ultimate self' (1984: 36).

8 In contrast to this image of the sexes united in origin and purpose, one might compare Thomas's 'Female', in H'm, and 'The Woman', from Frequencies, both variations on the creation of woman in which the female is depicted not, primarily, as in union with the male but as pitted against him in a struggle for power, as 'other', serpent-like and seductive.

9 Similarly to the idea I am suggesting here, Henry Vaughan's 'The Retreate' takes as its subject an intuited awareness of pre-existence, a 'remembered Eden'. 